\title{
PENGAMBILAN KEPUTUSAN SEBAGAI SUATU PROSES
}

\section{Ade Herawati Sahputri}

\section{adehera92@gmail.com}

\section{Latar Belakang}

Membuat keputusan merupakan bagian dari kehidupan kita sehari-hari baik secara individu ataupun secara kelompok, terutama dalam suatu organisasi. Pengambilan keputusan mempunyai arti penting bagi maju atau mundurnya suatu organisasi. Pengambilan keputusan yang tepat akan menghasilkan suatu perubahan terhadap organisasi ke arah yang lebih baik, namun sebaliknya pengambilan keputusan yang salah akan berdampak buruk pada roda organisasi dan administrasinya.

Setiap manusia memiliki tujuan yang hendak diraih. Tujuan tersebut dapat diraih secara "tersendiri", atau dicapai melalui kelompok. Organisasi merupakan wadah atau alat yang digunakan oleh manusia untuk mengkoordinasikan seluruh tindakan mereka dengan tujuan saling berinteraksi untuk mencapai sejumlah tujuan yang sama.

Organisasi muncul didorong oleh kemunculan sejumlah masalah dan tantangan yang harus dihadapi manusia. Masalah yang dihadapi oleh pengelolanya adalah menemukan kebijakan dan strategi terbaik agar organisasi tetap dapat bertahan hidup dan menciptakan kemakmuran bagi para pemilik maupun pengelolanya. Mencari solusi yang akan membantu kelangsungan hidup organisasi sehingga organisasi dapat terus menciptakan kemakmuran bagi pemiliknya merupakan tujuan utama dari pengambilan keputusan.

Tugas strategis seorang pimpinan adalah mengambil keputusan, maka seorang pimpinan dituntut punya kemampuan dalam mengambil keputusan, karena dari keputasan tersebutlah akan menentukan langkah selanjutnya, keputusan yang cepat tepat dan benar akan membawa kesuksesan suatu organisasi baik organisasi profit maupun non profit, begitu juga sebaliknya keputusan yang tidak tepat akan beresiko terhadap langkah berikutnya.

Sudarmo dalam Anwar (2014) berpendapat bahwa keputusan terkait dengan ketetapan atau penentuan suatu pilihan yang diinginkan. Bagian tersulit dari proses pengambilan keputusan adalah memisahkan gejala dari masalah. Dengan demikian pengambilan keputusan secara jernih akan mampu mengidentifikasi langkah yang harus diambil. Pengambilan keputusan merupakan suatu proses 
pemilihan alternatif terbaik dari beberapa alternatif secara sistematis untuk ditindaklanjuti (digunakan) sebagai suatu cara pemecahan masalah.

\section{Metode}

Metode yang digunakan dalam kajian ini adalah metode literature review yaitu metode dengan cara membaca dari berbagai sumber seperti jurnal online yang terbit terakhir pada tahun 2012 serta membandingkan isi dari berbagai sumber yang dibaca dan menyimpulkan dalam hasil kajian yang didapatkan pada jurnal online mengenai pengambilan keputusan dan tahap - tahap nya.

\section{Hasil}

Rizky Dermawan (2004:2 - 3 ) mengatakan pengambilan keputusan merupakan ilmu dan seni yang harus dicari, dipelajari, dimiliki, dikembangkan secara mendalam oleh setiap orang. Dikatakan seni karena kegiatannya selalu dihadapkan pada sejumlah peristiwa yang memiliki karakteristik keunikan tersendiri. Sedangkan dikatakan ilmu karena aktivitasnya memiliki sejumlah cara, metode, atau pendekatan yang bersifat sistematis, teratur dan $\mathrm{n}$ bahwa pengambilan keputusan adaterarah. Jogiyanto (2003:66) mengemukakalah tindakan manajemen di dalam pemilihan alternatif untuk mencapai sasaran. Maman Ukas (2004:140) mengemukakan pengambilan keputusan merupakan suatu pengakhiran dari proses pemikiran tentang suatu masalah yang dihadapi Siagian (1980:82) mengemukakan pengambilan keputusan adalah suatu pendekatan yang sistematis terhadap hakekat suatu masalah, pengumpulan fakta-fakta dan data, penentuan yang matang dari alternatif yang dihadapi dan mengambil tindakan yang menurut perhitungan merupakan tindakan yang paling tepat. Johanes Supranto (1998:1) memaparkan secara populer dapat dikatakan bahwa mengambil atau membuat keputusan berarti memilih satu di antara sekian banyak alternatif, yang dibuat dalam rangka untuk memecahkan permasalahan atau persoalan (problem solving).

Keputusan yang baik terjadi jika pengambil keputusan sepenuhnya mengerti latar belakang, tujuan dan sasaran, alternatif penyebab tindakan, serta konsekuensikonsekuensi yang mungkin timbul dari keputusan. Namun keputusan yang dibuat dengan baik belum tentu menjadi keputusan yang efektif.. Menurut Vroom dan Jago sebagaimana dikutip Hoy dan Miskel (2014) keputusan yang efektif bergantung pada tiga hal yaitu kualitas keputusan, penerimaan bawahan, dan ketepatan waktu. Keputusan dikatakan berkualitas jika mampu memecahkan masalah yang dihadapi seseorang atau organisasi. Keputusan yang efektif juga ditunjukkan 
dengan tidak adanya resistensi pada pelaksana dan pihak-pihak yang terkait langsung dengan keputusan. Akhirnya keputusan yang efektif terjadi bila dekat dengan waktu terjadinya permasalahan yang akan dipecahkan. Artinya keputusan yang efektif adalah keputusan yang dibuat dengan baik dan dapatdiimplementasikan dengan baik pula.

Proses pengambilan keputusan meliputi sebagai berikut : 1. Perumusan Masalah 2 . Pengumpulan dan Penganalisis Data 3. Pembuatan alternatif-alternatif kebijakan 4. Pemilihan salah satu alternatif terbaik 5 . Pelaksanaan keputusan 6. Pemantauan dan Pengevaluasian Hasil Pelaksanaan.

\section{Pembahasan}

Keputusan (decision) secara harfiah berarti pilihan (choice). Pilihan yang dimaksud di sini adalah pilihan dari dua atau lebih kemungkinan, atau dapat dikatakan pula sebagai keputusan dicapai setelah dilakukan pertimbangan dengan memilih satu kemungkinan pilihan. Seperti yang diungkapkan oleh Gito Sudarmo, bahwa keputusan terkait dengan ketetapan atau penentuan suatu pilihan yang diinginkan.

Definisi di atas mengandung pengertian, dalam keputusan yaitu: (1) ada pilihan atas dasar logika atau pertimbangan; (2) ada beberapa alternatif yang harus dipilih salah satu yang terbaik; dan (3) ada tujuan yang ingin dicapai dan keputusan itu makin mendekatkan pada tujuan tersebut.

Hakikatnya pengambilan keputusan adalah suatu pendekatan yang sistematis terhadap suatu masalah yang dihadapi. Pendekatan yang sistematis itu menyangkut pengetahuan tentang hakikat masalah yang dihadapi itu, pengum-pulan fakta dan data yang relevan dengan masalah yang dihadapi, analisis masalah dengan menggunakan fakta dan data, mencari alternatif pemecahan, menganalisis setiap alternatif sehingga ditemukan alternatif yang paling rasional, dan penilaian dari hasil yang dicapai sebagai akibat dari keputusan yang diambil.5 Sementara Kusnadi menjelaskan yang dimaksud dengan pengambilan keputusan adalah penetapan atau pemilihan suatu alternatif dari beberapa alternatif yang tersedia, dengan memperhatikan kondisi internal maupun eksternal yang ada

Thohiron menjelaskan proses pengambilan keputusan meliputi sebagai berikut :

\section{Perumusan Masalah}

Dalam hal ini pemimpin diharapkan mampu merumuskan masalah yang ada di dalam suatu organisasi. Suatu masalah hadir karena: a) adanya gap atau kesenjangan antara kenyataan, titik berangkat, dengan tujuan yang ingin diraih atau standar yang ingin dicapai; b) adanya 
halangan dan kesulitan untuk menjembatani kesenjangan itu; c) adanya kemungkinan penyelesaian masalah bila perumusannya benar.

Perumusan masalah juga terkait dengan sudut pandang. Karenanya beberapa proses harus dipastikan hadir. Apakah ciri suatu perumusan masalah yang baik? Sebuah perumusan yang baik mengidentifikasikan semua elemen-elemen yang relevan,elemen apa yang absen, dan elemen apa yang perlu ditambahkan.

Perumusan masalah dimulai dengan mengkaji fakta-fakta yang ada. Sering kali hal yang kedengarannya sederhana ini menjadi sumber kegagalan pengambilan keputusan yang benar. Masalah yang sering muncul dalam pengkajian fakta adalah pemimpin dan orang yang ada di sekitarnya sering membaurkan fakta dengan tafsiran tentang fakta tersebut. Sebuah perumusan yang baik mengidentifikasikan semua elemen-elemen yang relevan, elemen apa yang absen, dan elemen apa yang perlu ditambahkan.

2. Pengumpulan dan Penganalisis Data

Pemimpin diharapkan dapat mengumpulkan dan menganalisis data yang dapat membantu memecahkan masalah yang ada. Adapun proses pemecahan masalah dalam pengambilan keputusan yaitu: a) fase pengumpulan fakta; b) fase penemuan ide; c) fase penemuan solusi.

Fase pengumpulan data/fakta meliputi kegiatan mendefinisikan masalah serta mengumpulkan masalah serta menganalisis data yang penting. Satu cara untuk meningkatkan kemampuan pengumpulan data adalah dengan mulai dulu melihat masalah yang ada secara luas dan kemudian melanjutkannya dengan menentukan sub masalah yang ada. Dalam hal ini, diperlukan kemampuan untuk membedakan antara gejala dari masalah yang sebenarnya.

Fase penemuan ide meliputi kegiatan pengumpulan ide-ide yang mungkin dipakai dan kemudian mencari ide yang terbaik. Dapat saja berbagai ide yang ada dimodifikasi dan dikom-binasikan. Dalam hal ini, kegiatan curah pendapat (brainstorming) perlu dilakukan. Osborn telah menyediakan 75 buah pertanyaan untuk melaksanakan kegiatan curah pendapat ini. Pada dasarnya kegiatan curah pendapat mempunyai 4 aturan umum yaitu: ide yang ada tidak boleh dikritik terlebih dahulu, dapat saja disampaikan ide-ide yang kelihatannya di luar kebiasaan, makin banyak ide yang masuk maka hasil akan makin baik, dianjurkan adanya kombinasi antar satu ide dengan ide lainnya.

Fase penemuan solusi ini meliputi kegiatan mengidentifi-kasi dan mengevaluasi 
pemecahan yang mungkin dilakukan dan bagaimana cara melakukan. Kegiatan dalam fase ini meliputi penentuan pendapat, analisis dan penerimaan/pemberian kritik. Setiap ide yang ada diberi nilai/bobot masing-masing.

3. Pembuatan alternatif-alternatif kebijakan

Setelah masalah dirinci dengan tepat dan tersusun baik, maka perlu dipikirkan caracara pemecahannya. Cara peme-cahan ini hendaknya selalu diusahakan adanya alternatif-alter-natif beserta konsekuensinya, baik positif maupun negatif. Oleh sebab itu, seorang pimpinan harus dapat mengadakan perkiraan sebaikbaiknya. Untuk mengadakan perkiraan dibutuhkan adanya informasi yang secukupnya dan metode perkiraan yang baik. Perkiraan itu terdiri dari berbagai macam pengertian: a) perkiraan dalam arti proyeksi, perkiraan yang mengarah pada kecenderungan dari data yang telah terkumpul dan tersusun secara kronologis; b) perkiraan dalam arti prediksi, perkiraan yang dilakukan dengan menggunakan analisis sebab akibat; c ) perkiraan dalam arti konjeksi, perkiraan yang didasarkan pada kekuatan intuisi (perasaan). Intuisi di sini sifatnya subjektif, artinya tergantung dari kemampuan seseorang untuk mengolah perasaan.

4. Pemilihan salah satu alternatif terbaik
Pemilihan satu alternatif yang dianggap paling tepat untuk memecahkan masalah tertentu dilakukan atas dasar pertimbangan yang matang atau rekomendasi. Dalam pemilihan satu alternatif dibutuhkan waktu yang lama karena hal ini menentukan alternatif yang dipakai akan berhasil atau sebaliknya

.Pengambilan keputusan oleh pimpinan, kaitannya dengan pemilihan alternatif pemecahan masalah, akan melibatkan semua pihak yang terlibat dalam lembaga pendidikan. Hal ini karena kekuasaan pimpinan tidak dapat dioperasionalkan apabila tidak didukung dan dibantu oleh seluruh personal yang me-miliki pengetahuan dan pengalaman yang berbeda-beda. Pim-pinan harus mengembangkan konsep kerja sama antar personal agar pelaksanaan alternatif pemecahan masalah lebih cepat dan mudah. Kerja sama dapat diciptakan jika pimpinan memiliki keterampilan manusiawi.

5. Pelaksanaan keputusan

Dalam pelaksanaan keputusan berarti seorang pemimpin harus mampu menerima dampak yang positif atau negatif. Ketika menerima dampak yang negatif, pemimpin harus juga mempunyai alternatif yang lain. Pelaksanaan pengambilan ke-putusan sering menjadi masalah karena keputusan yang mesti ditanggapi oleh banyak orang 
malah ditangani oleh sedikit orang. Hal sebaliknya juga sering terjadi. Keputusan yang seharusnya dapat ditangani oleh 2-3 orang diserahkan kepada sebuah tim yang terdiri dari 40 orang atau lebih. Akibatnya timbul perdebatan yang tak henti-hentinya. Jadi tentukan dulu cara pengambilan keputusan yang paling cocok dengan situasi dan masalah yang ada: individu, tim, musyawarah, voting, dan lain-lain.

6. Pemantauan dan Pengevaluasian Hasil Pelaksanaan

Setelah keputusan dijalankan seharusnya pimpinan dapat mengukur dampak dari keputusan yang telah dibuat. Penilaian ulang perlu diadakan. Faktor-faktor penentu yang akan dinilai harus diputuskan sejak awal dan tidak setelah pelaksanaan ber-jalan. Dengan cara ini memang akan mudah terjadi debat yang hangat, namun akurasi akan lebih terjamin.

\section{Penutup}

Pengambilan keputusan adalah proses pemilihan alternatif terbaik untuk pemecahan suatu masalah melalui metode dan teknik tertentu. maka disimpulkan tahapan proses pengambilan keputusan yang dimaksud dalam penelitian ini adalah: 1) perumusan masalah, 2) penentuan kriteria pemecahan masalah, 3) pengidentifikasian alternatif pemecahan masalah, 4) penilaian terhadap alternatif pemecahan masalah, 5) pemilihan alternatif yang terbaik, 6) penetapan keputusan atau pengimplementasian alternatif yang dipilih

\section{Daftar Pustaka}

Anwar, Herson. 2014. Proses Pengambilan Keputusan untuk Mengembangkan Mutu Madrasah. Jurnal Pendidikan Islam. 8 (1). Hal 38 - 55

Latifa, Ade. 2012. APLIKASI MODEL PENGAMBILAN KEPUTUSAN DALAM PERILAKU FERTILITAS. Jurnal Kependudukan Indonesia. 5 (1). Hal $58-63$

Moordiningsih dan Faturochman. 2015. Proses Pengambilan Keputusan Dokter (Physician Decision Making). Jurnal Psikologi. 33 (2). hal $1-15$

Muhdi dkk. 2017. Teknik Pengambilan Keputusan Dalam Menentukan Model Manajemen Pendidikan Menengah. Jurnal Manajemen Pendidikan. 4 (2). hal 134 - 145

Mukhtadi dan Mohammad Rizki. 2018. STRATEGI PENGAMBILAN KEPUTUSAN DALAM PEMECAHAN MASALAH (STUDI KASUS PADA BANK XYZ CABANG TAJUR HALANG CIANJUR JAWA BARAT). Journal of Aseanomics (JEBA). 3 . 
(1). Hal 83- 97

Rohayuningsih, Heri. 2015. BERPIKIR

KREATIF

DALAM

PENGAMBILAN KEPUTUSAN.

FORUM ILMU SOSIAL. 42 (1).

hal. 106 - 113

Sabri, Ahmad. 2013. KEBIJAKAN DAN

PENGAMBILAN KEPUTUSAN

DALAM LEMBAGA

PENDIDIKAN ISLAM. Jurnal Al-

Ta'lim. 1(5). Hal 375 - 378

Santoso, Budi. 2012. KUNCI

KEBERHASILAN PROSES

PENGAMBILAN KEPUTUSAN.

Jurnal MANAJERIAL. 8 (16) . hal.

$28-33$

Simamora, R. H. (2019). Menjadi perawat

yang: CIH'HUY. Surakarta:

Kekata Publisher.

SOLA, ERMI. 2018. DECISION

MAKING: Sebuah Telaah Awal.

JURNAL IDAARAH. 2 (2). hal.

$208-215$

Tadanugi, Imanuel. 2013. PROSES PENGAMBILAN KEPUTUSAN DALAM PENYELENGGARAN PEMERINTAHAN DI KANTOR CAMAT PAMONA SELATAN KABUPATEN POSO. Jurnal Administratie. 1 (1). hal 8 - 14 